\title{
STUDY THE EFFECT OF DRY FERMENTATION OF GOAT MANURE IN OPTIMIZATION OF BIOGAS PRODUCTION AND MINIMIZATION OF COSTS.
}

\section{H. H. Mohamed ${ }^{1}$ and M. I. Morsy ${ }^{2}$}

\begin{abstract}
In this study the effects of temperature, fermentation type and hydraulic retention time were investigated to optimize biogas yield and minimize production costs under lab scale for batch anaerobic digestion of goat manure. The growth and activity of anaerobic microorganisms is influenced by some parameters like temperature, moisture content, pHvalue and volatile fatty acids (VFA), which were measured before the study. The methane values were between (61.89 - 69.35\%). A cost equation was determined to calculate the total biogas cost LE/liter at different conditions. The minimum biogas production cost was 4.09 LE/liter at the highest cumulative production of 128.74 liter at temperature of $60^{\circ} \mathrm{C}$ for dry fermentation.
\end{abstract}

Key words: Goat Manure, dry fermentation, biogas, production cost.

\section{INTRODUCTION}

The increase in production of organic wastes is considered one of the main environmental problems in Egypt, so that the sustainable waste management as well as waste prevention has become major political priorities, representing an important share of the common efforts to reduce pollution and greenhouse gas emissions and to decrease global climate changes. (Al Seadi et al. 2008).

Rashed (2014) reported that anaerobic digestion (AD) is the process of decomposition of organic matter by various types of anaerobic bacteria in the absence of oxygen to produce biogas in reactor tanks, commonly named digesters. A wide range of micro-organisms are involved in the anaerobic process to produce biogas and digestion product.

1-Lecturer, Soil \& Ag. Eng. Dept., Fac of Agric. Saba Basha, Alexandria University, Egypt.

2- Lecturer, Agric. \& Biosystems Eng. Dept., Fac. of Agric. El-Shatby, Alexandria University, Egypt. 
Biogas is a combustible gas consisting of methane ( $\mathrm{CH} 4)$, carbon dioxide (CO2) and trace gases such as hydrogen and sulphide. Digestion product is the decomposed material, which is rich in macro and micro nutrients and therefore suitable to be used as plant fertilizer.

Field et al. (2008) reported that the use of agricultural waste as a source of renewable energy is suitable for improving energy security and decreasing environmental disruption caused by carbon emissions.

Angelidaki et al. (2003) reported that the growth and activity of anaerobic microorganisms is significantly influenced by temperature, $\mathrm{pH}$ value, volatile fatty acids (VFA), ammonia and microelements. The anaerobic digestion (AD) process take place by different temperatures, divided into three ranges: psychrophilic bacteria (below $25 \mathrm{C}^{\mathrm{o}}$ ), mesophilic bacteria $\left(25-45 \mathrm{C}^{\circ}\right)$, and thermophilic bacteria $\left(45-70 \mathrm{C}^{\circ}\right)$. The $\mathrm{pH}$ value of the organic matter influences the growth of methanogenic microorganisms and affects the dissolution of some compounds of importance for the AD process. The methane formation takes place within a relatively narrow $\mathrm{pH}$ interval, from about 5.5 to 8.5. The value of $\mathrm{pH}$ can be increased by ammonia, produced during degradation of proteins or by the presence of ammonia in the feed stream, while the accumulation of VFA decreases the $\mathrm{pH}$-value. Microelements (trace elements) like iron, nickel, cobalt, selenium, molybdenum or tungsten are equally important for the growth and survival of the $\mathrm{AD}$ microorganisms as the macronutrients carbon, nitrogen, phosphor, and sulphur. The optimal ratio of the macronutrients carbon, nitrogen, phosphor, and sulphur (C:N:P:S) is considered 600:15:5:1. The hydraulic retention time (HRT) is an important parameter for economical biogas production. The HRT is the average time interval when the waste is kept inside the digester tank. The duplication rate of anaerobic bacteria is usually 10 days or more. A short HRT provides a good substrate flow rate, but a lower gas yield. It is therefore important to adapt the HRT to the specific decomposition rate of the used substrates.

Borhan et al. (2012) fabricated a laboratory scale dry anaerobic digestion system to use with feedlot manure and inoculums mix at a ratio of 2:1 and was evaluated for a 40 day hydraulic retention time (HRT) under a $35 \pm 2^{\circ} \mathrm{C}$ digestion temperature. The main constituents of biogas identified and 
quantified were methane $\left(\mathrm{CH}_{4}\right)$, carbon dioxide $\left(\mathrm{CO}_{2}\right)$, and nitrous oxide $\left(\mathrm{N}_{2} \mathrm{O}\right)$. The average concentrations of $\mathrm{CH}_{4}$ and $\mathrm{CO}_{2}$ were $49 \%$, and $44 \%$ respectively after 40 day.

This research was carried out to:

1- Optimize biogas yield from goat manure.

2- Minimize biogas production costs

3- Minimize hydraulic retention time.

\section{MATERIALS AND METHODS}

This research was carried out in the laboratory of Soil and Agricultural Engineering dept., Faculty of Agriculture Saba Basha, Alexandria University. The experiment was done to evaluate the effect of temperature, fermentation type and hydraulic retention time (HRT) as shown in Fig. (1). on the biogas production from goat manure on a laboratory digester to maximize gas production and minimize each of costs and hydraulic retention time. All experiments were done under batch system, which the wastes have been added once to the digester for whole duration of the process. The average batch weight for each digester was about $4 \mathrm{~kg}$.

\section{1-Materials:}

\section{1-1- Structure of the anaerobic digestion System}

The anaerobic digesters consist of six glass bottles ( 5 liter) equipped with rubber stoppers, which produce biogas at temperature of $40,60 \mathrm{C}^{\mathrm{o}}$ and ambient temperature from goat manure for hydraulic retention time of 80 day. The digesters were placed in an isolated water bath, where the temperature was controlled by $1200 \mathrm{~W}$ electric heater and thermostat. The digester rubber stopper is attached with a silicon tube to transfer biogas to plastic bottle (20 liter) filled with water at a specified level. The plastic bottle is attached with a silicon tube to transfer water to an empty plastic bottle (20 liter). The daily biogas production was recorded by measuring the collected water in the empty plastic bottle.

\section{1-2- Goat manure (GM)}

Goat population in Egypt is about 2.5 million head produce about 2400787.5 ton of wastes per year. Goat manure consists of undigested 
residue of plant matter which has passed through the animal's gut. The resultant semi-decomposed organic matter rich in minerals and bacteria to break down organic matter and produce large amount of biogas. Goat manure is an excellent raw material for anaerobic digestion because of its high total nitrogen content and fermentation stability. The goat manure was obtained from a local farm. The goat manure was analyzed for chemical characteristic as shown in Table (1). The total solid (TS) for dry fermentation was $30 \%$ while was $10 \%$ for wet fermentation.

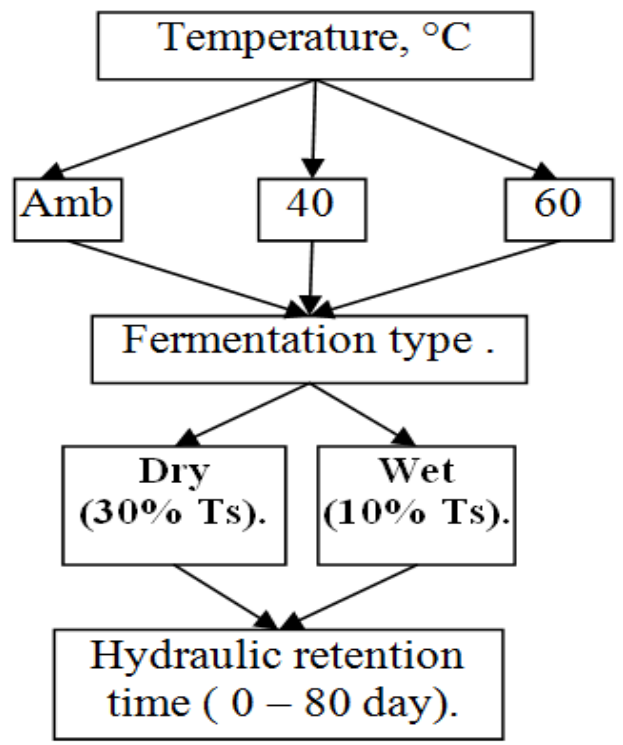

Fig.(1): Factors under study.

Table (1). Chemical characteristic for goat manure.

\begin{tabular}{|c|c|}
\hline Characteristics & Goat manure \\
\hline Moisture content (M.C), \% & $66.39 \pm 3.12$ \\
\hline Total solids (T.S), \% & $33.61 \pm 3.12$ \\
\hline Volatile solids (V.S), \% & $82.21 \pm 8.93$ \\
\hline Total organic carbon (T.C), \% & $18.22 \pm 1.14$ \\
\hline Total nitrogen (T.N), \% & $1.014 \pm 0.11$ \\
\hline Carbon / Nitrogen ratio (C/N ratio) & $17.92 \pm 0.81$ \\
\hline pH & $7.92 \pm 0.14$ \\
\hline potassium, \% $\left(\mathrm{K}_{2} \mathrm{O}\right)$ & 3.2 \\
\hline phosphorus, \% $\left(\mathrm{P}_{2} \mathrm{O}_{5}\right)$ & 0.53 \\
\hline
\end{tabular}




\section{2-Methodology:}

Laboratory experiments were carried out to maximize biogas production from anaerobic digesters of goat manure. All laboratory experiments were done at $\mathrm{pH}$ from (6-8) and hydraulic retention time of 80 days.

\section{2-1- Measurements:}

A-The amount of water required to adjust the total solids of goat manure was calculated according to Lo et al. (1981) as follows:

$\mathrm{D}_{\mathrm{w}}=\mathrm{R}_{\mathrm{m}}\left[\frac{\mathrm{TS}_{\mathrm{m}}-\mathrm{TS}_{\mathrm{d}}}{\mathrm{TS}_{\mathrm{d}}}\right]$

Where:

$\mathrm{D}_{\mathrm{W}}=$ water required, $\mathrm{kg}$;

$\mathrm{R}_{\mathrm{m}}=$ raw material weight, $\mathrm{kg}$;

$\mathrm{TS}_{\mathrm{m}}=$ total solid in raw materials; $\%$ and,

$\mathrm{TS}_{\mathrm{d}}=$ total solids in fermentation materials, $\%$.

B- The total solids (TS) of organic waste samples were determined by drying samples in oven at $105^{\circ} \mathrm{c}$ for 24 hours to calculate the weighed of the samples before and after drying. The total solids were calculated using the following equation according to (Peces, 2014).

$$
\mathrm{Ts}=\frac{\mathrm{Wd}}{\mathrm{Ww}} * 100
$$

Where:

Ts: Total solids, $\%$

Wd: Dry sample weight, gm

Ww: Wet sample weight, gm

C- The total volatile solids were determined from total solids using incineration oven at $600^{\circ} \mathrm{C}$ for 2 hours. The difference between the weights of the total solids and the ash gave the total volatile solids using the following equation according to (Peces, 2014).

$$
\mathrm{Tv}_{\mathrm{S}}=\mathrm{T}_{\mathrm{S}}-\mathrm{A}_{\mathrm{h}}
$$

Where:

$$
\begin{aligned}
& \mathrm{Tv}_{\mathrm{s}}: \text { Total volatile solids, } \% \\
& \mathrm{~T}_{\mathrm{s}}: \text { Total solids, } \% \\
& \mathrm{~A}_{\mathrm{h}}: \text { Ash, } \% .
\end{aligned}
$$




\section{D- Organic matter and organic carbon (O.M \& O.C):}

The percentage of organic matter was estimated from the percentage of ash at $\left(550-600{ }^{\circ} \mathrm{C}\right)$ for 24 hours using the following equation according to (Peces, 2014).

Organic matter, $\%=100-$ ash, $\%$

Organic carbon, $\%=\frac{\text { Organic matter, } \%}{1.724}$

Where 1.724 is Van Bemmelen factor.

E-The moisture content of waste samples were estimated by drying oven at $105 \pm 1{ }^{\circ} \mathrm{C}$ for $24 \mathrm{~h}$ (Suthar and Das, 1996). The desired moisture content for dry and wet fermentation was equipped by adding calculated amounts of distilled water to waste samples.

$\mathbf{F}$ - The $\mathbf{p H}$ is a hydrogen ion concentration in a solution, indicating its acidity or alkalinity. The $\mathrm{pH}$ meter (daigger 5500) was used to measure the $\mathrm{pH}$ values for goat manure with ranged from 6.00 to 20 with an accuracy of $+/-0.01$. The $\mathrm{pH}$ meter should be calibrated by using at least two buffers. (Ukpai and Nnabuchi, 2012)

G- The biogas composition was determined by biogas analyzer to measure the percentage of $\mathrm{CH}_{4}(0-100 \%), \mathrm{CO}_{2}(0-100 \%), \mathrm{O}_{2}(0-25 \%), \mathrm{H}_{2}$ (0-1000ppm), $\mathrm{NH}_{3}(0-1000 \mathrm{ppm})$ and $\mathrm{H}_{2} \mathrm{~S}(0-10,000 \mathrm{ppm})$ in the biogas.

\section{1- Factors affecting biogas production}

\section{RESULTS AND DISCUSSION}

\section{1-1 Hydraulic retention time (HRT):}

Hydraulic retention time is the time that the waste spends in the digester. The relationships between daily and cumulative biogas production per liter and the time per day for dry and wet fermentation at temperatures of 40, 60 and ambient temperature $\mathrm{C}^{\mathrm{o}}$ are shown in Fig. (2). For all experiments the biogas production rate, liter/day was increased with the time until reached the maximum production value and then the biogas production was decreased until stopped.

It was observed that the highest biogas production rates by dry fermentation were 2.74 liter/day in the 50th day, 7.64 liter/day in the 11th day and 3.06 liter/day in the 11th day at temperature of 40,60 and $a m b{ }^{\circ} \mathrm{C}$ respectively, while were 5.23 liter/day in the 11 th day , 5.07 liter/day in 
the 11th day and 3.1 liter/day in the 23th day by wet fermentation at the above mention temperatures respectively.
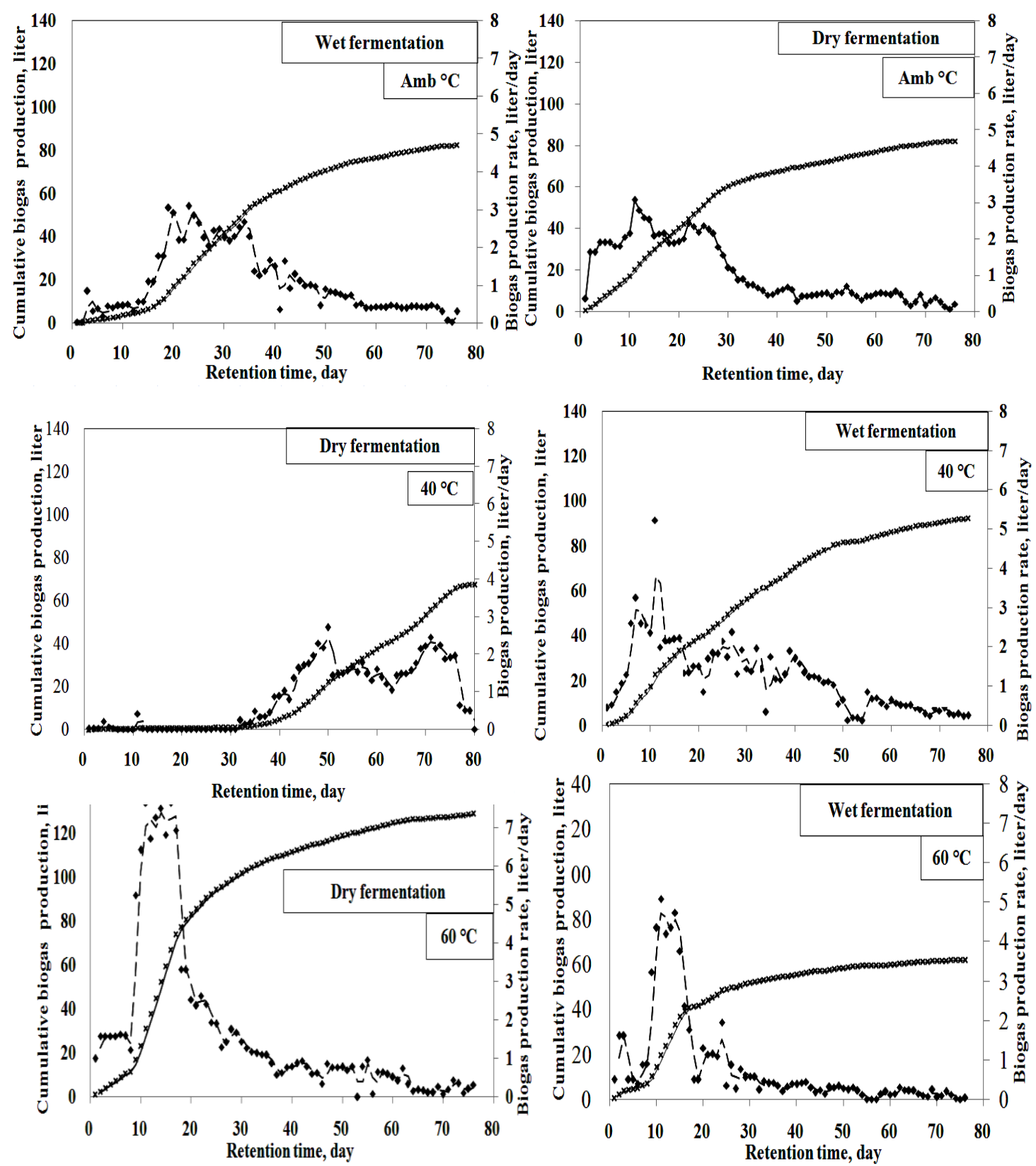

$\times$ Cumulative biogas production, liter - Biogas production, liter/day

Fig. (2). Daily and cumulative biogas production by dry and wet fermentation at temp of 40, 60 and ambient ${ }^{\circ} \mathrm{C}$. 
The cumulative biogas productions by dry fermentation were 58.95, 128.74 and 82.07 liter, while were $92.25,61.72$ and 82.56 liter by wet fermentation at temperature of 40,60 and ambient temperature ${ }^{\circ} \mathrm{C}$ respectively. The highest cumulative biogas production was 128.74 liter by dry fermentation at temperature of $60{ }^{\circ} \mathrm{C}$, while the lowest cumulative biogas production was 58.95 liter by dry fermentation at temperature of $40{ }^{\circ} \mathrm{C}$.

\section{1-2 Temperature:}

The cumulative biogas productions by dry fermentation were 58.95, 128.74 and 82.07 liter, while were $92.25,61.72$ and 82.56 liter by wet fermentation at temperature of 40, 60 and ambient temperature ${ }^{\circ} \mathrm{C}$ respectively. The highest cumulative biogas production was 128.74 liter by dry fermentation at temperature of $60{ }^{\circ} \mathrm{C}$, while the lowest cumulative biogas production was 58.95 liter by dry fermentation at temperature of $40{ }^{\circ} \mathrm{C}$.

The temperature is an important factor affecting the growth, activity and survival of microorganisms. The effects of temperature on the cumulative biogas production for dry and wet fermentation are shown in Figs. (3 and 4). It was observed that the cumulative biogas production was increased with the time until reach the maximum values for all temperatures.

The highest cumulative biogas production by dry fermentation was 128.74 liter at temperature of $60{ }^{\circ} \mathrm{C}$ and followed by 82.07 liter at ambient temperature, while the lowest cumulative biogas production was 58.95 liter at temperature of $40^{\circ} \mathrm{C}$ as shown in Fig. (3).

The highest cumulative biogas production by wet fermentation was 92.25 liter at temperature of $40{ }^{\circ} \mathrm{C}$ and followed by 82.56 liter at ambient temperature, while the lowest production was 61.72 liter at temperature of $60{ }^{\circ} \mathrm{C}$ as shown in Fig. (4).

The cumulative biogas production for wet fermentation at temperature of $40^{\circ} \mathrm{C}$ was higher than $60^{\circ} \mathrm{C}$, because Mesophiles bacteria produces biogas for about 50 day with medium digestion rate, while thermophiles bacteria at $60^{\circ} \mathrm{C}$ produces biogas for about 30 day with high digestion rate. So the thermophilic conditions require less retention time and produce less amount of biogas than mesophilic condition at wet fermentation. 


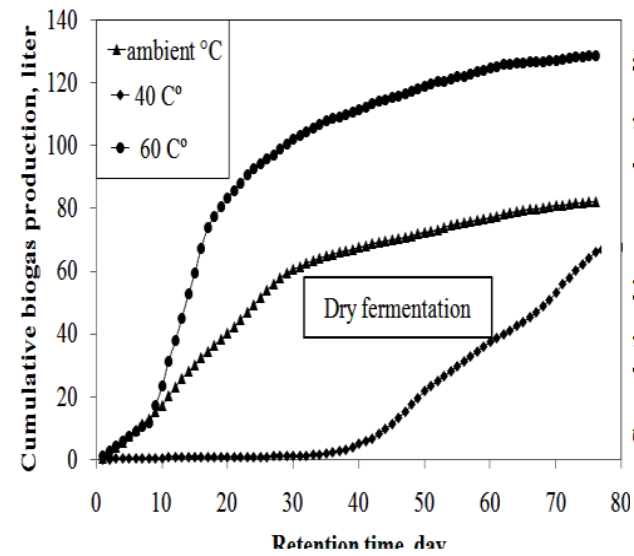

Fig. (3). Effect of temperature on the cumulative biogas production by dry fermentation.

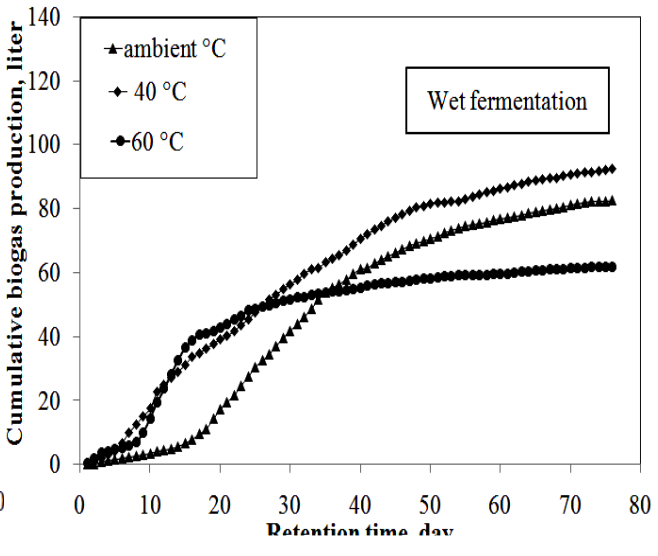

Fig. (4). Effect of temperature on the cumulative biogas production by wet fermentation.

The cumulative biogas production for dry fermentation at temperature of $60^{\circ} \mathrm{C}$ was higher than $40^{\circ} \mathrm{C}$, because the Mesophiles bacteria produces biogas for about 40 day with medium digestion rate, while the thermophiles bacteria produces biogas for about 40 day at $60^{\circ} \mathrm{C}$ with high digestion rate. So the thermophilic conditions produces higher amount of biogas than mesophilic condition at dry fermentation, these results are consistent with (Rashed 2014).

At ambient temperature the cumulative biogas production by dry and wet fermentation take the same trend.

\section{1-3 Fermentation type:}

The effect of fermentation type on the cumulative biogas production at the above mention temperatures are shown in Figs. (5, 6 and 7). It was observed that the cumulative biogas production was increased with the time until reach the maximum values for dry and wet fermentation.

The cumulative biogas production by dry fermentation was higher than wet fermentation at temperature of $60{ }^{\circ} \mathrm{C}$, which due to the total solids of dry fermentation was $30 \%$ of the total waste sample about $1.2 \mathrm{~kg}$ of $4 \mathrm{~kg}$ sample, while at wet fermentation the total solids was $10 \%$ of the total waste sample about $0.40 \mathrm{~kg}$ of $4 \mathrm{~kg}$ sample, so that the production of biogas by dry fermentation was higher than wet fermentation because the total solids at dry fermentation sample was higher than in wet fermentation by about 3 times and the activity of thermophiles bacteria is better at dry fermentation to convert organic matter into biogas. 
BIOLOGICAL ENGINEERING

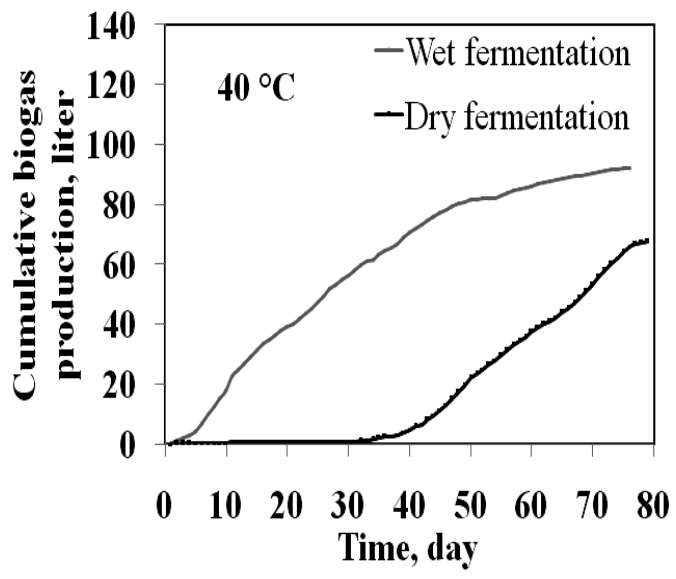

Fig. (5). Cumulative biogas production by dry and wet fermentation at temp. of $40{ }^{\circ} \mathrm{C}$.

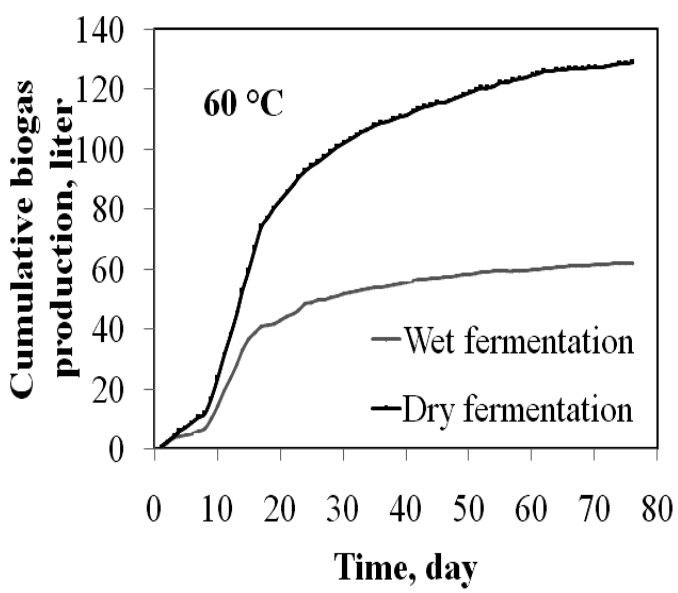

Fig. (6). Cumulative biogas production by dry and wet fermentation at temp. of $60{ }^{\circ} \mathrm{C}$.

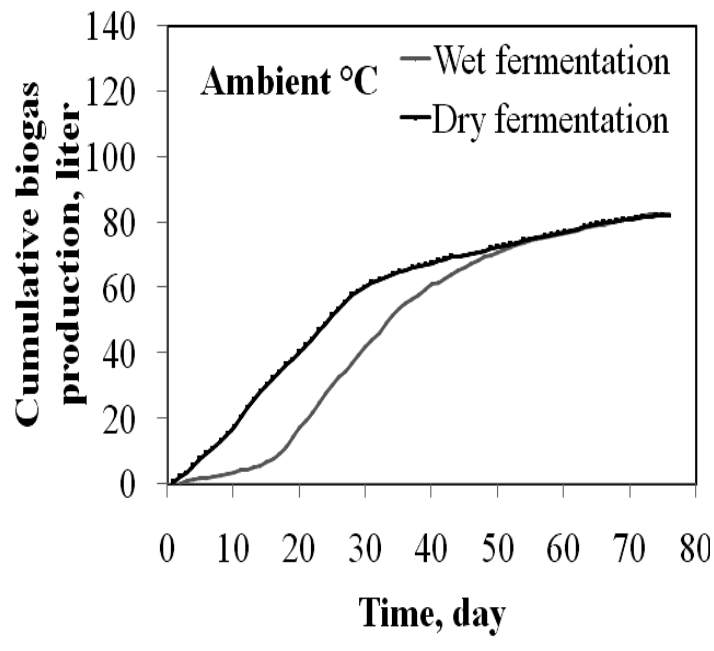

Fig. (7). Cumulative biogas production by dry and wet fermentation at ambient temp. ${ }^{\circ} \mathrm{C}$.

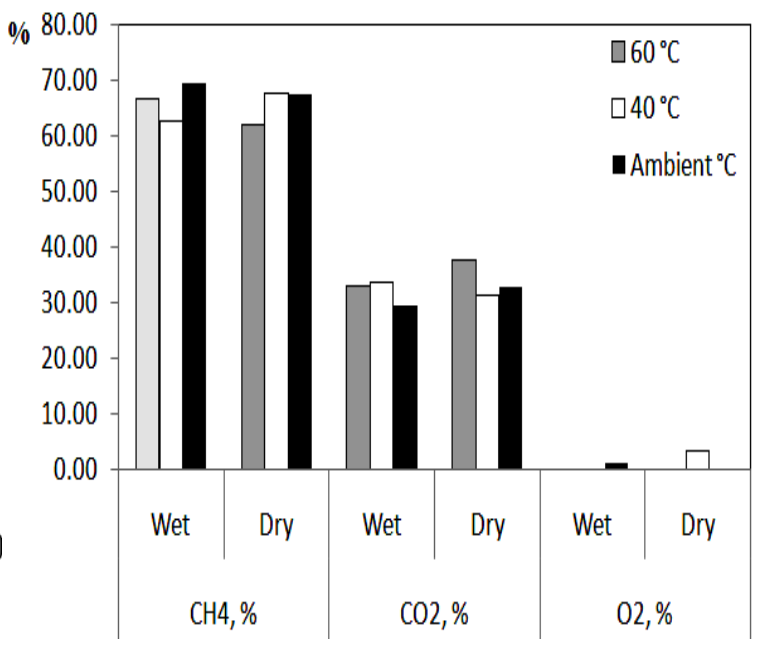

Fig. (8). Average biogas constituents by dry and wet fermentation at temp. of 40,60 and $\mathrm{amb}{ }^{\circ} \mathrm{C}$.

At temperature of $40{ }^{\circ} \mathrm{C}$ the cumulative biogas production by wet fermentation was higher than dry fermentation, which due to the activity of mesophiles bacteria at wet fermentation is better than dry fermentation these results are consistent with (Rashed 2014).

At ambient temperature the cumulative biogas production by dry and wet fermentation take the same trend. 


\section{2- Biogas constituents}

The biogas is a mixture of methane $\mathrm{CH}_{4}(50-75 \%)$, carbon dioxide $\mathrm{CO}_{2}$ (25-50), nitrogen $\mathrm{N}_{2}(0-10)$, hydrogen $\mathrm{H}_{2}(0-1 \%)$, Hydrogen sulfide $\mathrm{H}_{2} \mathrm{~S}$ $(0-3 \%)$ and oxygen $\mathrm{O}_{2}(0-3 \%)$. The methane is the most important element in biogas mixture because it is flammable and can be use as a fuel. The composition of biogas varies depending upon the anaerobic digestion process, to ensure optimum operation of the biological process and achieve the maximum methane yield, a biogas composition must be continuously monitored temperature, $\mathrm{pH}$, hydraulic retention time, $\mathrm{C}: \mathrm{N}$ ratio, volatile fatty acids, trace gases and the addition of substrate. The average biogas constituents for goat manure are shown in Table (2) and Fig.(8). The methane average values were between $(61.89-69.35 \%)$.

Table (2). Average biogas constituents.

\begin{tabular}{ccccccc}
\hline \multirow{2}{*}{$\begin{array}{c}\text { Temp, } \\
{ }^{\circ} \mathrm{C}\end{array}$} & \multicolumn{2}{c}{$\mathbf{C H 4} \%$} & \multicolumn{2}{c}{ CO2, \% } & \multicolumn{2}{c}{ O2, \% } \\
\cline { 2 - 7 } & Wet & Dry & Wet & Dry & Wet & Dry \\
\hline $\mathbf{6 0}$ & 66.67 & 61.89 & 33.13 & 37.90 & 0.20 & 0.18 \\
\hline $\mathbf{4 0}$ & 62.27 & 67.67 & 33.92 & 31.625 & 0.23 & 3.5 \\
\hline Ambient & 69.35 & 67.23 & 29.35 & 32.617 & 1.23 & 0.18 \\
\hline
\end{tabular}

\section{3-Biogas production costs analysis}

\section{3-1- Construction costs of biogas system:}

The laboratory biogas production system consists of six glass bottles ( 5 liter), 12 rubber stoppers, isolated water bath, electric heater with thermostat $1200 \mathrm{~W}, 20$ meter silicon tube and 12 plastic bottles (20 liter). The total construction cost for each laboratory digester was LE 175, while the total cost for six digesters was LE 1050. The total volume of the six laboratory digester is 30 liter, so it is too small to produce biogas economically; also the construction cost of laboratory digester is too high.

\section{3-2- Raw material cost:}

The cost of raw material is considered the most important factor which affects biogas price. The price of edible crops like wheat and corn are too high to produce biogas, on the other hand using these crops in biogas production increase food prices. Goat manure is a good source for biogas production because it is available semi-decomposed organic matter rich in bacteria, non edible and clean energy source. According to the local 
prices the average cost of collecting and transportation $1024 \mathrm{~kg}$ of goat manure is about LE 80 (\$4.7). The laboratory digester needs about $4 \mathrm{~kg}$ wastes with cost of LE 0.31 .

The biogas production digester should be built inside animal farms to minimize collecting and transportation cost for economically biogas production.

\section{3-3-Heating cost:}

An electric heater was used to heat the water bath, where the temperature was fixed on 40 or $60^{\circ} \mathrm{C}$ by thermostat. The electric energy consumption for heating one digester was about 1.63, 1.84 and zero kW.h per day at temperature of 40, 60 and $\mathrm{Amp}{ }^{\circ} \mathrm{C}$ respectively, which was measured by digital multi-meter. The electric energy cost for heating one digester was about 0.40, 0.46 and zero LE per day at temperature of 40, 60 and Amp ${ }^{\circ} \mathrm{C}$ respectively.

\section{3-4 - Workers cost:}

The laboratory biogas production needs one technician to control biogas production stages such as, heating and gas transfer between units, the workers cost was about LE 50 (\$3.12) per day for six digesters.

\section{Table (3). Biogas production costs.}

\begin{tabular}{|c|c|c|c|c|c|c|c|c|c|}
\hline \multirow{2}{*}{$\begin{array}{l}\text { Temp, } \\
{ }^{\circ} \mathrm{C}\end{array}$} & \multirow{2}{*}{\multicolumn{2}{|c|}{$\begin{array}{c}\begin{array}{c}\text { Hydraulic } \\
\text { retention time }\end{array} \\
\text { Dry fer Wet fer }\end{array}$}} & \multicolumn{2}{|c|}{$\begin{array}{c}\text { Cumulative } \\
\text { production, liter }\end{array}$} & \multirow{2}{*}{$\begin{array}{l}\text { Construction } \\
\text { costs } \\
\text { LE/ digester }\end{array}$} & \multirow{2}{*}{$\begin{array}{l}\text { Worker cost } \\
\text { LE/day }\end{array}$} & \multirow{2}{*}{$\begin{array}{l}\text { Electric cost } \\
\text { LEdday }\end{array}$} & \multicolumn{2}{|c|}{$\begin{array}{c}\text { Total biogas cos } \\
\text { LE/liter }\end{array}$} \\
\hline & & & Dry fer & Wet fer & & & & Dry fer & Wet fer \\
\hline 40 & 80 & 50 & 58.95 & 92.25 & 175.31 & 8.33 & 0.407 & 14.83 & 6.64 \\
\hline 60 & 40 & 30 & 128.74 & 61.72 & 175.31 & 8.33 & 0.46 & 4.09 & 7.11 \\
\hline amb & 40 & 50 & 82.07 & 82.56 & 175.31 & 8.33 & 0 & 6.20 & 7.17 \\
\hline
\end{tabular}

\section{3-5-Total biogas production costs:}

The total biogas production cost consists of construction cost, worker cost, electricity cost and row material cost as shown in table (3).

A cost equation was determined to calculate the total biogas production cost.

$$
\mathrm{Tbc}=\frac{\mathbf{C c}+(\mathbf{W o c} * \mathbf{H r t})+(\mathbf{E l c} * \mathbf{H r t})+\left(\mathbf{W a c} * \frac{\mathbf{H r t}}{40}\right)}{\text { Bip }}
$$

Where:

Tbc is total biogas cost, LE/liter

$\mathrm{C}_{\mathrm{c}}$ is construction cost of biogas system, LE 
Woc is worker cost, LE/day

Hrt is hydraulic retention time, day

Elc is electricity cost, LE/day

$\mathrm{W}_{\text {ac }}$ is raw material cost every 40 days, $\mathrm{LE}$

$\mathrm{Bip}$ is biogas production volume, liter

It was observed that increasing hydraulic retention time resulted in increasing worker cost, electricity cost and the total biogas production costs as shown in Table (3)., so it is important to minimize hydraulic retention time and maximize cumulative biogas yield to minimize the total costs. The total biogas production costs for dry fermentation was 14.38, 4.09 and 6.2 LE/liter at temperature of 40, 60 and ambient temp ${ }^{\circ} \mathrm{C}$ respectively, while was $6.64,7.11$ and $7.17 \mathrm{LE} /$ liter for wet fermentation at the above mention temperatures respectively.

The minimum total biogas production cost was $4.09 \mathrm{LE} / \mathrm{liter}$ at the highest cumulative production of 128.74 liter which equal 25 times of digester volume ( 5 liter) at temperature of $60{ }^{\circ} \mathrm{C}$ for dry fermentation.

\section{3-6-The recommended biogas unit for minimize costs}

In order to minimize biogas production costs a local commercial digester $\left(\left\ulcorner\mathrm{m}^{3}\right)\right.$ equipped with a solar heater can be use to control the digester temperature. The construction cost of this system is LE 12000 with shelf life of 10 years. The produced gas volume is about 25 time digester volume every 40 days at dry fermentation of goat manure at temperature of $60{ }^{\circ} \mathrm{C}$. Through ten years the digester produces about $6825 \mathrm{~m}^{3}$ of biogas, which suitable for small family (4 people) the average biogas consumption for one person is about $0.4 \mathrm{~m}^{3} /$ day.

The total biogas production cost can be reduced to $0.029 \mathrm{LE} /$ liter by using this recommended digester.

\section{CONCLUSIONS}

The highest cumulative biogas production was 128.74 liter by dry fermentation at temperature of $60{ }^{\circ} \mathrm{C}$, while the lowest cumulative biogas production was 58.95 liter by dry fermentation at temperature of $40{ }^{\circ} \mathrm{C}$. The average methane production were between $(61.89-69.35 \%)$ for all treatments. The total biogas production costs for dry fermentation was 14.38, 4.09 and 6.2 LE/liter at temperature of 40,60 and ambient temp ${ }^{\circ} \mathrm{C}$ 
respectively, while was $6.64,7.11$ and 7.17 LE/liter for wet fermentation at the above mention temperatures respectively.

The lowest biogas production cost was $4.09 \mathrm{LE} /$ liter at the highest cumulative biogas production of 128.74 liter at temperature of $60{ }^{\circ} \mathrm{C}$ for dry fermentation. It is recommended to use a local digester $\left(3 \mathrm{~m}^{3}\right)$ with solar heater to produce about $6825 \mathrm{~m}^{3}$ of biogas in 10 years and minimize total biogas production cost to $0.029 \mathrm{LE} /$ liter.

\section{REFERENCES}

Al Seadi, T.; D. Rutz, and R. Janssen, 2008. Biogas Handbook. Published by University of Southern Denmark Esbjerg, Niels Bohrs Vej, DK6700 Esbjerg, Denmark, pp. 9-10.

Angelidaki, I.; L. Ellegaard, and B. K. Ahring, 2003. Applications of the anaerobic digestion process. Advances in biochemical engineering II, vol. 82. Berlin: Springer; 2003. pp. 1-33.

Bhattacharya, T. K. and T. N. Mishra, (2003). Biodegradability of dairy cattle manure under dry anaerobic fermentation process. J. Inst. Engineers (India): Agricul. Eng., 84: 9-11.

Borhan, M. S.; R. Shafiqur, and K. Heekwon, 2012. Dry Anaerobic Digestion of Fresh Feed yard Manure: A Case Study in a Laboratory Setting. Int. J. Emerg. Sci., 2(4), 509-525, December ISSN: 2222-4254.

Field CB, Campbell JE, Lobell DB (2008) Biomass energy: the scale of the potential resource. Trend Ecol Evolut 23: 65-72.

Jingura, R. M., R. Matengaifa, 2009. Optimization of biogas production by anaerobic digestion for sustainable energy development in Zimbabwe. Renewable and Sustainable Energy Reviews;135:1116-20.

Lo, K.V.; W.M. Carson and K. Jeffers, 1981. A computer-aided design for biogas production from animal manure. Livestock Wastes. A Renewable Resource, p:133-135, 141.

Peces, M.; S. Astals, and J. M. Alvarez, 2014. Assessing total and volatile solids in municipal solid waste samples. Environmental Technology.12/ 2014DOI: 10.1080/09593·Source: PubMed 
Rashed, M. B. 2014. The Effect of Temperature on the biogas Production from Olive Pumice. University Bulletin - ISSUE No.16- Vol. (3).

Suthar, S. H. and S. K. Das, 1996. Some physical properties of karingda seeds. Journal of Agricultural Engineering Research, 65(1), 15-22.

Ukpai, P. A. and M. N. Nnabuchi, 2012. Comparative study of biogas production from cow dung, cow pea and cassava peeling using 45 litres biogas digester. Advances in Applied Science Research, 3 (3):1864-1869. ISSN: 0976-8610.

الملخص العربي

\section{دراسة تأثير استخدام التخمر الجاف لمخلفات الماعز في تعظيم إنتاج الغاز الحيوي وتقليل التكاليف

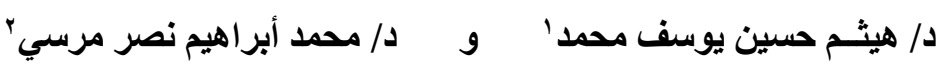

تعتبر مصر هي أكبر منتج للنفط خارج منظمة أوبك وثناني أكبر منتج للغاز الطبيعي في أفريقيا.

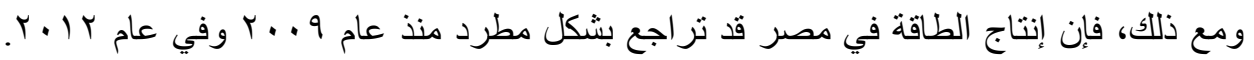

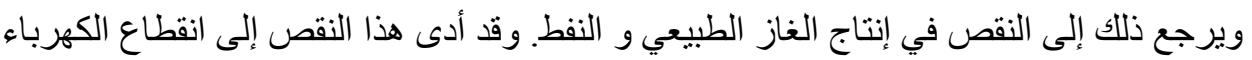

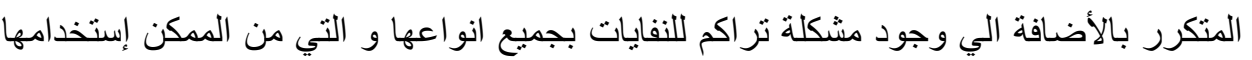

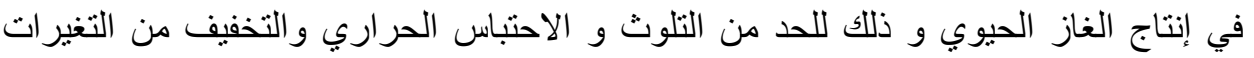

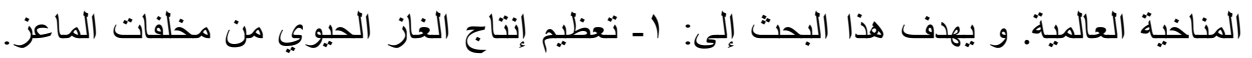

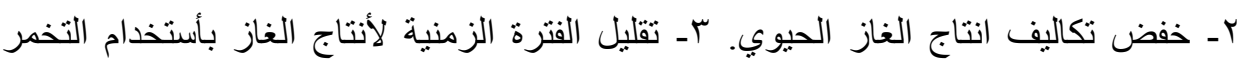

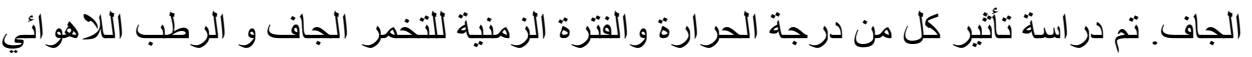

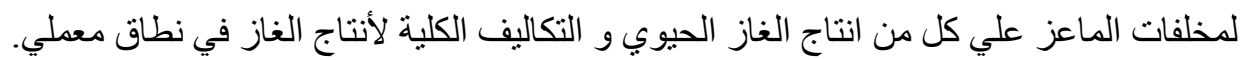

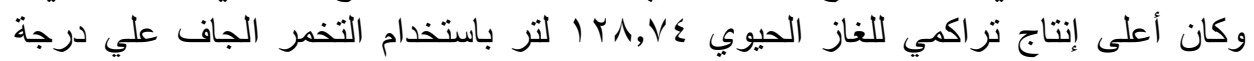

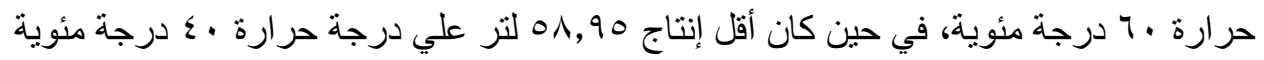

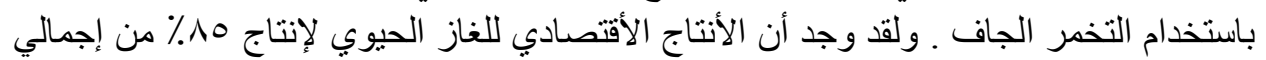

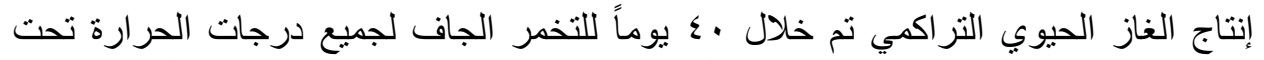

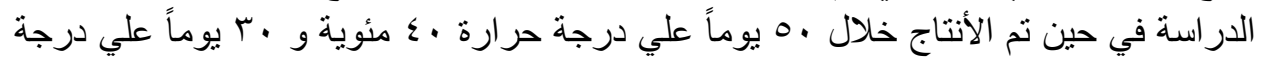

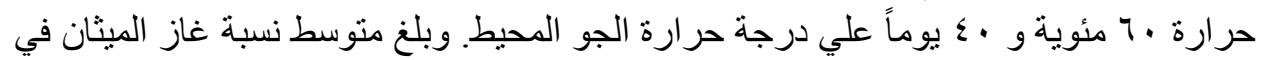

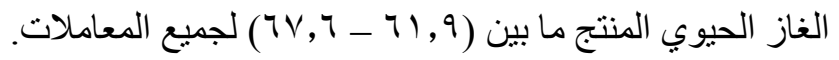

1 - مدرس الهندسة الزراعية - قسم الأراضي و الكيمياء الزراعية - كلية الزراعة ساباباشا - جامعة الأسكندرية.

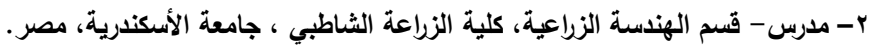




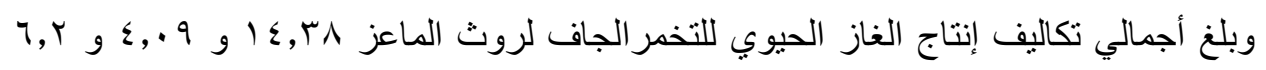

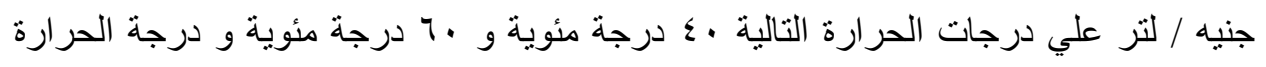

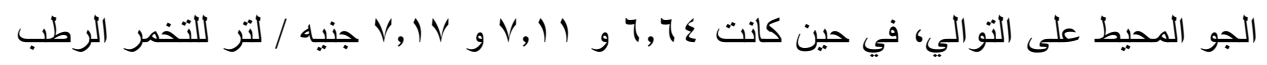

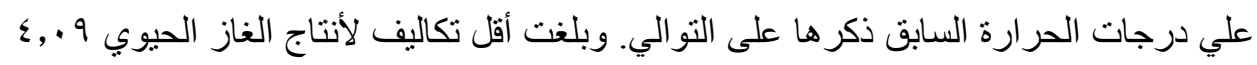

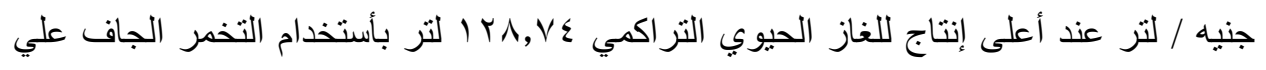
درجة حر ارة · ب د درجة مئوية.

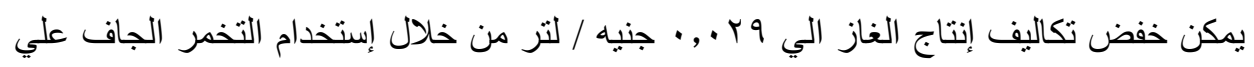

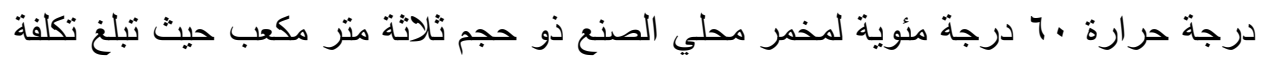

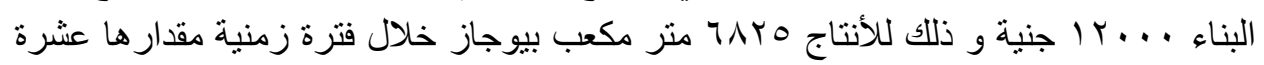

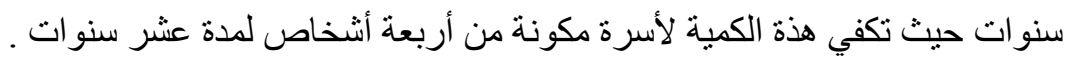

